\title{
Hyssop Oil
}

National Cancer Institute

\section{Source}

National Cancer Institute. Hyssop Oil. NCI Thesaurus. Code C71765.

The oil extracted from the leaves and flowering tops of Hyssopus officinalis. Hyssop oil is used in aromatherapy and for the treatment of respiratory illnesses. In higher concentrations hyssop oil can causes convulsions. 